\title{
Reuna
}

\section{TOWARDS NEW BUSINESS MODELS: STRATEGIES AND PLANNING OF BRAZILIAN STARTUPS IN DIGITAL ENVIRONMENT}

\section{RUMO À NOVOS MODELOS DE NEGÓCIOS: ESTRATÉGIAS E PLANEJAMENTO DE STARTUPS BRASILEIRAS EM AMBIENTE DIGITAL}

http://dx.doi.org/10.21714/2179-8834/2019v24n2p25-43

\author{
Rodrigo Hipólito Roza \\ Pontifícia Universidade Católica de Campinas (PUC-Campinas), Brasil. \\ E-mail: rodrigo.roza@gmail.com
}

\section{Samuel Carvalho De Benedicto}

Pontifícia Universidade Católica de Campinas (PUC-Campinas), Brasil.

E-mail: samuel.benedicto@puc-campinas.edu.br

\author{
André Luiz Zambalde \\ Universidade Federal de Lavras (UFLA), Brasil. \\ E-mail: zambaufla@gmail.com
}

Submissão: 30 set. 2018 Publicação: 15 out. 2019. Sistema de avaliação: Double blind review. Centro Universitário UNA, Belo Horizonte - MG, Brasil. Editor geral: Prof. Dr. Gustavo Quiroga Souki

Este artigo encontra-se disponível nos seguintes endereços eletrônicos:

http://revistas.una.br/index.php/reuna/article/view/1092

http://dx.doi.org/10.21714/2179-8834/2019v24n2p25-43

\begin{abstract}
The objective of this study is to deepen the understanding of the process of defining strategies and planning of Brazilian startups in a digital environment, in order to create new and innovative business models. The research was applied, with a qualitative and exploratory approach. For that, a semi-structured roadmap was elaborated. Based on the script, two professionals were interviewed in leadership positions in two Brazilian companies, with a broad experience in the digital environment startup market. The first company is a global leader in the development of platforms for commerce and mobile content. The second is one of the largest in the world in the segment of software development and electronic products. From the analysis of the results obtained, this study provides guidelines for the new entrepreneurs and for the new ventures, in what concerns the definition of strategies and the planning of startups in digital environment, towards new business models.
\end{abstract}

Keywords: Startup; Business Model; Digital Environment; Entrepreneurship; Innovation. 


\section{Resumo}

O objetivo deste estudo foi de aprofundar a compreensão sobre o processo de definição de estratégias e planejamento de startups brasileiras em ambiente digital, tendo em vista a criação de novos e inovadores modelos de negócios. A pesquisa foi aplicada, com abordagem qualitativa e exploratória. Para isso, foi elaborado um roteiro semiestruturado. Com base no roteiro, foram entrevistados dois profissionais em posições de liderança em duas empresas brasileiras, com ampla experiência no mercado de startups em ambiente digital. A primeira empresa é líder global no desenvolvimento de plataformas para comércio e conteúdo móvel. A segunda é uma das maiores do mundo no segmento de desenvolvimento de software e produtos eletrônicos. A partir da análise dos resultados obtidos, este estudo fornece diretrizes para os novos empreendedores e para os novos empreendimentos, no que diz respeito à definição de estratégias e planejamento de startups em ambiente digital, rumo a novos modelos de negócios.

Palavras-chave: Startup; Modelo de Negócios; Ambiente Digital; Empreendedorismo; Inovação.

\section{Introduction}

The concept of startups refers to an innovative business or business that uses a traditional idea and reinvents it to offer products or services to the society. These innovative organizations are more frequent in digital environment, and especially on the Internet. However, they may also be associated with other areas of knowledge, such as agribusiness or biotechnology, for example (Ries, 2012; Gitahy, 2016).

According to Blank (2013), a startup is not a miniature company. There is a great uncertainty and ambiguities, typical of companies in the process of creation (Medeiros Júnior et al., 2015), unlike an already consolidated company that has well defined processes of operation. In the future, startups can be profitable and scaleable, with experience and customers. In the beginning, however, it is in search of a business model (Casadesus-Masanell; Ricart, 2010; Teixeira, 2014), of its ideology and the construction of a culture that gives it identity.

In digital environment, startups rely on so-called information and communication technologies (ICTs), resulting from technological advances in computing and telecommunications (Roza, 2017). They use and benefit from different forms of business and e-commerce (Chaffey, 2014; LAUDON; TRAVER, 2016; TURBAN, et al., 2017), as well as they reinvent them to explore new markets.

The movement to create digital startups has intensified in recent years, but there are many difficulties faced by these organizations. In the Brazilian reality, in particular, the obstacles to the establishment and survival of startups are great (Azevedo et al., 2018). Given the uncertainties and growth potential of the digital startups, how to strategize and properly plan a startup to increase its chances of success? Considering these aspects, the present study had as main objective to deepen the understanding on the process of definition of strategies and planning of Brazilian startups in digital environment, towards new business models. 


\section{Theoretical foundation}

The theoretical basis of the research focused on three main topics: the first deals with the theme of business models with a focus on the digital age; the second deals with possible strategies for digital startups; the third topic deals with planning, emphasizing the concept of the lean startup, as opposed to the conventional planning model.

\subsection{Business Model}

The term business model was often initiated by consultants, executives and academics, mainly after the emergence of the Internet business, becoming one of the most popular expressions in the business world (Teixeira, 2014). These business models emerged from the value-creation studies of dot-com companies in the 1990s. However, the most developed business models are conceptual design, which creates an important theoretical gap (Zott; Amit, 2010; Casadesus-Masanell; Zhu, 2013).

Business models are a reflection of business strategy. A strategy is a plan of actions, where the objects of choice are the business models. The complexity and quantity of choices involved in the business model are based on the strategy to be developed by the company, even if it is not explicit in the eyes of the managers (Casadesus-Masanell; Ricart, 2010).

According to Teixeira (2014), a business model describes the essential details of a company's value proposition for its various audiences, as well as the system of activities that the company uses to create and deliver value to its customers. However, unlike strategy, business models do not consider a company's competitive positioning.

The business model plays a relevant role in the success of an organization, because it explains how the company generates, obtains and creates value for stakeholders (Zott; Amit, 2010). The business model lists all the relevant components for the implementation of a business, facilitates the visualization of the company's operation and "allows both the perception of the key activities and the key resources that can be the origin of the competitive advantages of the organization". "Building a business model helps the stakeholders to understand the various nuances of the business they are in, such as partners, products/services, risks, market, costs, sources of revenue, resources, etc." Other function of a business model is "to guide and follow the development of the company in the short, medium and long term, according to the goals established by the company" (Teixeira, 2014, p.15).

As the concept of business model is polychrome, lacking a common theoretical framework (Zott et al., 2011; Spieth et al., 2014), there is also no single set of components of the business model (Ritter; Letti, 2018). What is perceived is the divergent nature presented by scholars about the components of a business model (Fjeldstad; Snow, 2018, DaSilva; Trkman, 2014). Thus, the theme of business model still represents a slippery construction to study, needing to establish consensus and resolve doubts (Casadesus-Masanell; Zhu, 2013).

Among the divergences presented, three aspects seem to be common among researchers. In the analysis of the business model, it is necessary to consider both the internal organization (value chain) and external organization (value network). So, the essence of a business model lies in the definition by which the firm delivers value, 
induces customers to pay for the value, and converts those payments into profit (Teece, 2010). Therefore, a business model: (i) is composed of a variety of strategic elements such as products, customers, technologies, resources, market, etc. (Teixeira, 2014); (ii) includes the creation of customer value as one of the fundamental elements (Amit; Zott, 2012); (iii) considers the return on investments made in the form of profit (Nenonen; Storbacka, 2010).

The aforementioned strategic elements must be planned, organized and integrated within the company in order to achieve a determined and expected result. The resources and capabilities that the company has (core competence, resources, assets, processes, activities) should be used strategically (Casadesus-Masanell; Ricart, 2010). Strategic decisions are discussed in the scientific literature by using terms such as "target market", "position within the value network", "target customer", "competitive strategy", or "rules" (Nenonen; Storbacka, 2010). Thus, the literature review indicates that the business model construct can also explain the main strategic decisions made by the company (Teixeira, 2014).

The customer value creation is discussed under various terms such as "value creation project", "value proposition", "value creation", but the main content of these terms is the same: the business model should explain how the company creates value for its customers (Amit; Zott, 2012). The logic of gains or returns on investments is addressed in various business model definitions by using terms such as "profit potential", "revenue model", "revenue logic", "value capture", "profit", or "return to stakeholders" (Nenonen; Storbacka, 2010).

As the firm grows, it adds activities that relate to some degree to existing activities, and levels of coherence may vary by learning aspects, by the firm's history (internal) and by the selection of the environment (external) (Teixeira, 2014). The creation and management of the interactions among the main components creates firm performance and can also serve to initiate or sustain virtuous circles (Lecocq et al., 2010). The Figure 1 summarizes this cycle. 


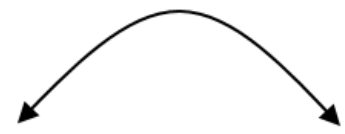

Interface with the customer

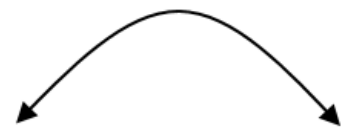

Strategic Resources

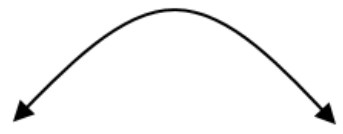

Value network
Central Strategy
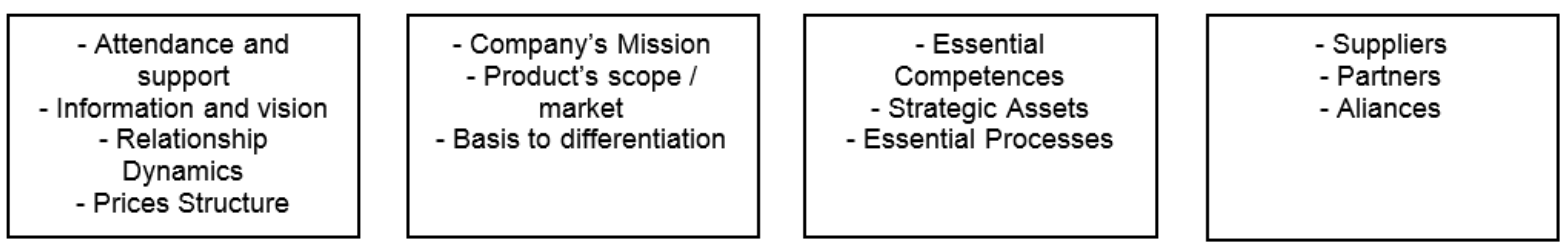

EFICIENCY / UNICITY / PRECISION / PROFIT

Figure 1 - Value added potential of a business model.

Source: Adapted from Teixeira (2014).

The business model is intimately connected with the business strategy, but it is not itself a strategy (Gonzales; Campos, 2015). The business model should reflect the company's strategic choices, which implies that these precede that. A business model is only concerned with the viability of the basic business concept; even if the business model is robust, the company needs a strategy that allows it to survive against competitors who are using the same business model (Teixeira, 2014).

Business models are not completely fixed structures and therefore must be modified and adapted to the reality of the market and the needs of the company. Faced with digital transformations, new business models are already a reality. It is not yet possible to say when traditional models will be extinct, but it will certainly be necessary to live with traditional models for many years. Therefore, betting on digital transformation is the safest way, both for companies that are committed to current models and those that bet on more traditional models. However, it is also important to remember that it takes a change of mentality: offering a product for free may seem silly, but the freemium model proves that it can be a good strategy. Decentralized businesses, focused on the experience and convenience of the client, are those with the greatest chances of success (Ciccone, 2017).

\subsection{Startup strategies}

There are two types of spaces in the market: the spaces that everyone already knows, called the red ocean, and the unknown space, called the blue ocean (Kim; Mauborgne, 2005). For companies competing with each other, models, standards and rules of action define their limitations to gain more and more the market and the greater 
part of the demands of the clients, that is, they end up fighting (red ocean) for the greater profit. For blue ocean companies is quite the opposite. They end up creating a need, a demand, for the customer, taking their profit without having to compete with other organizations because the rules, standards and models have not yet been established.

Many of these companies in the red ocean act, most of the time, reactively to the market. They respond to the demands of the customers, the movements of the competition and the dynamics of the sector in which they compete. This reactivity is also contained within their business, that is, the strategy used, the marketing practiced and the innovation are also reactive. The biggest problem with this reactivity is when it becomes the only option for the company, making it hostage to the consumer demand (Gava, 2009).

However, it is important that the company is not only reactive to the market, but rather the orient, transforming it and creating conditions that come into force and are exploited as the basis for success in a new scope of business. For this, it is necessary to anticipate organizations and startups in face of market changes, creating a new momentum for the industry and generating the necessary demand for its innovation (Gava, 2009). As proposed by Miles and Snow (1978), these fields of analysis of the company's reactivity and proactivity represent a theoretical orientation for the market. From this, Jaworski, Kohli and Sahay (2000) explain the concept of market driving, in which organizations begin to consider the market that can be modulated, their strategic choice transforms the structure and behavior of the environment, making these organizations the innovators and leading market leaders.

The market-driving orientation reflects the idea of a proactive company and aims to build an integrative model and research propositions that seek the implementation of this type of strategy. This approach is translated into a more aggressive stance based on proactivity, with the clear objective of influencing market structures and/or behavior. On the other hand, Jaworski, Kohli and Sahay (2000) describe that the reactive market model is based on the concept of market-driven, giving the idea of a market driven orientation, in detriment of the quest to modify the predominant premises, representing making decisions based on the recognition of preferences and behaviors of customers, consumers and competitors.

The market space in the blue ocean does not seek to overcome competition, since it tries to avoid it (Barbero; Vieira, 2015; Kim et al., 2008), making it irrelevant to its growth process and maturation in the context in which it is inserted. With this strategic logics, different from the one adopted by companies in the red ocean, startups are distinguished by their innovation. The important thing is not to meet the consumer's need, but to show what may be necessary for the consumer. So, it is considered that the customer does not know what he wants until he is shown what he needs. It is this whole system that transforms the design of blue oceans into a sustainable strategy.

Another important characteristic that companies that seek to create blue oceans end up is that they do not traditionally fall into just one type of strategy, for example, cost leadership or differentiation, as emphasized by Porter (1996). They, at least initially, seek to use the two strategies to excel in their innovation. While the blue ocean strategy makes it easier for companies to excel, it is not an easy task to maximize opportunities while minimizing the risk of designing and executing strategies. Of course there will always be risks in any new business, as well as for companies that are 
already in the market. Startups, in particular, are exposed to various risks by dealing with high levels of uncertainty and dynamism (Todeschini et al., 2017). Thus, the differentiation factor is the efficacy to minimize these risks.

In order to make competition irrelevant, Kim and Mauborgne (2005) explore the value assessment matrix. The purpose of this matrix is to capture the current state of the known market space by allowing the companies to understand what competitors are investing in, based on product, service and delivery competition and what customers receive from any competitive offers in the market. This matrix analyzes and diagnoses innovation of essential value to startups and the creation of a blue ocean. As the strategic focus of competition shifts to alternative and non-buyer divisions, the company develops new concepts on how to redefine the difficulty of the particular industry, and thereby identifies value characteristics for beyond conventional sectoral boundaries. The usual strategic nexus, in contrast, induces companies to offer better solutions than those of their competitors, according to the value characteristics already determined by the sector.

Kim and Mauborgne (2005) also address the four-action model, in order to restore the elements of value to consumers. In this model, four questions identify which attributes can be eliminated, reduced, raised or created, resulting in a new value curve (Leavy, 2018). Through the first two actions (elimination and reduction of properties) the organization develops new ideas on how to improve its cost composition compared to its opponents. The other two actions (elevation and creation), on the other hand, provide insights on how to add value to customers and designate a new demand. Consolidated, these four actions allow methodologically finding ways of rearranging the attributes that generate value for buyers through alternative industries, providing these entirely new experiences while keeping their cost structure down. In the business world, elimination and creation are of the utmost importance for organizations to go beyond the practices of maximizing the value of their already determined attributes among their competitors, forcing companies to change their own characteristics and competition rules become irrelevant to their position in the market. The effect of the application of the four-action model on the value assessment matrix of the sector is the discovery of new features in the reading of old uncontested facts.

Highlighting the transcendence of the simple focus on the client and the importance of other factors in the business landscape, the strategic approach to market orientation arises seeking to perfect the traditional orientation for marketing. With this in mind, the market-orientation strategy represents a clearly adaptive focus approach (Jaworski et al., 2000), precisely because of the prominence of the market in its very essence. Simply getting information about the environment, processing it and acting based on the information seized is a responsive process, restricting radical innovations by positioning the market and its variables as an existing reality.

\subsection{Planning and lean startup}

In the conventional planning model, according to Blank (2006), the first action undertaken by the entrepreneur is to elaborate a business plan - a static document that gives the dimension of the opportunity, exposes the problem to be solved and suggests the new development. In short, such plan contains estimates of revenue, profit and cash flow for the following years. It starts from the premise that it is possible to answer most business questions beforehand, before the entrepreneur raise capital 
and put the idea into practice. A business plan is, fundamentally, a research learning done in isolation by an entrepreneur, before he even started to create a product.

In contrast to the conventional planning model, the concept of lean startup has been widely explored today (Frederiksen; Brem, 2017; Yang et al., 2018). This concept, according to Ries (2012), is related to a collection of processes that seek the development of a product or a market, based on the customer development (Blank, 2006). The lean startup initiative advocates the creation of fast prototypes that aim to add value to the customer, having more revenue than what is spent on the marketed product (Sarmento; Costa, 2016).

Although this lean approach may seem effective, Ladd (2016) points out that having a strong strategy is much more valid than conducting numerous market experiments. He explains that several successive trials erode the relationship with clients, generating a confidence gap with the client, since there is excessive feedback and constant change or deviation of the tested projects, which can also cause a high level of fatigue involved with continuous testing and process disruption. In this sense, the author describes that some ideas deserve to be interrupted during the development process due to non-demand generation, but that negative feedbacks may be producing false notions about the product or service in question. Good ideas, in the wrong way, would be rejected and wasted.

With this in view, Ladd (2016) cites the Harvard Business School professor, David Collis, who proposes a solution to this case. The teacher explains that to avoid good ideas being discarded without necessity, the lean strategy should establish clear constraints for the target markets and methods considered, while testing and refining the business model of the company. This means that entrepreneurs should set a limit on when it would be necessary to interrupt or continue a new business, thus enabling a better decision making. In addition, entrepreneurs need to ask themselves which aspects of the business model to build on first, since not all of them are likely to be important for the initial phase of the project. In this way, it is essential that the entrepreneur focuses on the target market, on the value proposition and also on the form of distribution of the product or service.

In the context of lean startup, Ries (2012) highlights an essential issue for the start of a business, called Metrics of Vanity. This metric translates the real situation of the new enterprise. For example, a site may be one of the most visited, but it can sell very little, being one of the sites that least profit from the products offered. However, this does not mean that the business had no market potential, but rather that there is some flaw in its construction. In addition, Ries (2012) also addresses, in the context of lean startup, three important steps that form a cycle of evaluation of a new business, which correspond to the actions of building, measuring and learning (Kalgovas, 2015; Terho et al., 2017). This cycle is explained as follows: it is necessary to transform ideas into products, measure how consumers react and learn from results. With this, it is needed a quality implementation, a good measurement, other than hastily, and learn from what was done during this process.

Blank (2006), recognized by the development of the customer development methodology (Sousa Neto; Cavalcanti, 2016; Trim; Berbegal-Mirabent, 2012), that launched the basis for the lean startup movement, writes the idea that has as basis the validated learning, the scientific experimentation, the reduction of product development cycles, the progress measures and the customer feedback. This approach aims to 
improve the entrepreneurial strategies, reducing the work, the expense of legitimating assumptions about the market and the time necessary for the business to find market traction. Its product is referred to as "minimally viable product" or MVP (Moogk, 2012; Terho et al., 2017), ie an unfinished but functional product. In this way, the intention is for the product to be adapted according to the customer's feedback, having subsequently the specific needs of its consumers served.

\section{Research method}

This research is applied, with a qualitative and exploratory approach. According Vilaça (2010), the applied research has as motivation the need to produce knowledge to apply its results, with the purpose of contributing to practical purposes, aiming at solving the problem found in the reality. The qualitative research involves an interpretive approach to the world, which means that its researchers study things in their natural settings, trying to understand the phenomena in terms of the meanings people impart to them (Denzin; Lincoln, 2006). For Gil (2019), an exploratory research has as main concern to familiarize itself with a subject still little known or explored. This type of research involves an interview with people who have had practical experiences with similar problems or analysis of similar examples that can stimulate the understanding of the studied phenomenon.

The semi-structured interview technique was used to collect data (Gerhardt; Silveira, 2009), covering the following topics: startup concepts; lean strategy for startups; first steps; company focus; social impact; moment to launch the product; startup growth; profit with applications; costs; and trend. In order to contemplate these topics, and based on the theoretical reference of the research, ten questions were compiled that compose the interview script of this study. The interview script is shown below:

1. What is startup? Why is there a belief that startups exist only in digital environment?

2. What is the importance of creating new demands for products and services in digital environment? How do they impact society?

3. When should a new business in digital environment be created? Is there an ideal time?

4. What should be the process of maturation of digital startups in the face of constant changes in the market and the constant need for innovation?

5. Faced with the risks inherent in any new business, how to minimize the costs for creating digital startups?

6. How to assess the effectiveness of lean and planned strategies? Is any of them better suited for digital startups?

7. From a business idea, what are the main steps to be taken to constitute a digital startup?

8. What should be the focus of the entrepreneur in the case of the digital startup?

9. What are the implications of the diversification of strategies commonly adopted by digital startups? 
10. In light of the above, new business models appear in the market, including those that offer free products and services. Is it possible, for example, to make a profit with free apps? What other aspects could be highlighted considering the trends for the startup market in digital environment?

The answers to the questions of the interview script were recorded and later, its main passages were transcribed, with minor adjustments of language, without, however, compromising its content. The results obtained from the interviews, covering both the concordant and discordant responses, are presented on results and discussion section. For each question in the interview script, the discussion of the results is also carried out, with the analysis of the answers in connection with the theoretical basis of the present research.

In this research, the interviewees were two professionals from two companies with wide experience with startups. The general strategy used for the analysis of the data was the discourse analysis, which has theoretical foundation in the works of several authors (Foucault, 2012; Melo, 2009). For Berger and Luckman (2014, p. 5760 ) the language "is an objective repository of vast accumulations of meanings that have their primary reference in everyday experiences". The interviews were conducted with the two professionals at the same time. In this way, we sought to create a space of confluence and opposition of ideas. In some questions, there was a full agreement of one interviewee regarding the response of the other. In this case, therefore, only one answer was reported as representative of the opinion of both.

\section{Results and discussion}

\subsection{Description of the interwiees and organizations}

The first professional (interviewee 1) has years of experience in the market and is currently a business controller, with the main attribution of promoting the development of platforms for commerce and mobile content, with products for smartphones and tablets. The second interviewee (interviewee 2) is currently in the field of cloud computing sales and primarily works with partners and startup innovation projects.

Interviewee 1's company is a global leader in the area of mobile content and trade platform development. The company of the interviewee 2 is one of the largests in the world in the segment of software development and electronic products.

\subsection{Strategies and planning}

For the first question, about the meaning of startup and the belief about its existence only in digital environment, it is observed that the startup is seen by the interviewees as any company that has innovation as the main idea, acting in a differentiated way in the market. There is, therefore, consonance with what is found in the scientific literature. Like Ries (2012), interviewees do not limit the startup concept to innovative companies only in digital environment. They are more frequent in this digital branch as it is cheaper and faster. In addition, it should also be noted that, according to Blank (2013), startup is not a miniature company. There is a great deal of 
uncertainty, unlike an already consolidated company that has specific operating processes. Only in the future it can be profitable and scalable, with experience and customers. In the beginning, it is in search of a business model (Casadesus-Masanell; Ricart, 2010; Teixeira, 2014; Teece, 2010; Zott; Amit, 2010) and its ideology and consolidation of a culture. It can be observed that a startup is the birth of a company already differentiated in the market that, in the beginning, is discovering itself as a company and seeking to add value to the customer through its product or service.

In the case of the importance of creating demand for products and services in the digital environment and its influence on society, it was possible to verify that the rise of technology, as highlighted by Roza (2017), boosted the advance in communication and information networks, making the areas of knowledge expand and provide innovative ideas for different types of markets and areas in society. Thus, the awareness that a product or service must meet or improve not only a specific point of a given area, but also offer scalable solutions to social problems has been broadened. This makes the value innovations highlighted by Kim and Mauborgne (2005) based also on customer feedback as essential for this evolution to continue, improving and spreading to various regions.

In the question of the best time to start a new business, launching a digital environment startup, Kim and Mauborgne (2005) treat timing in a way that is slightly different from those interviewed, called "strategic movement" where it is possible the creation of new markets for a good or service, having to be coherent to the time in which it is inserted. However, in the same way as Blank (2006), the interviewee 2 defends the idea of adapting the product according to customer feedback, ie a "minimally viable product" (MVP), without its final configuration ready for delivery. This is punctuated by the interviewee due to the fact that, nowadays, both the technological advance and the great advance in communication stimulate and accelerate the process of developing a startup, the new companies can not waste time to launch their products or services on the market. Thus, it is important to note that both the timing and MVP factors within a digital environment startup should be thought out and analyzed according to the type of product or service that the startup wants to offer to its customer in order to launch it without reaching the market too soon or too late.

In the question about the maturation process of startups in the face of market changes, respondents point out the importance of continuous improvement in their internal processes, as well as the need for innovation. In this sense, it is worth rescuing the concept of blue ocean. Kim and Mauborgne (2005) explain that the blue ocean strategy tries to avoid competition during its development, that is, the startup needs to find a way so that a possible competition is already eliminated without harming the company market. The success of some applications, for example, has brought consumers the necessary factor that makes competition irrelevant according to the authors, which is value innovation along with technology resources, linking the useful to the practical. The authors also explore the matrix of value evaluation, which aims to analyze the current market space already known, in order to identify and explore a new concept of value for the customer, that is, create a new demand without needing to reinvent itself throughout its maturing and growth process.

As pointed out in the interview, the process of reinventing itself is shown to be important in its development since, as the startup is growing and its number of consumers too, its internal controls and processes need to "walk" along with this high demand so that it does not lose future clients. In addition, it is seen that, of course, RELUNA, Belo Horizonte - MG, Brasil, v.24, n.2, p.25-43, Abr. - Jun. 2019 - ISSN 2179-8834 
there will be competition, just as Facebook did with the application Snapchat, using a feature of this that meets the same goal for the user.

With this, it is noted that somehow, at the beginning of a startup, the companies need to assess the degree that their product or service innovation will bring to the consumers. That means having a good reading of the market and also intuition to observe the impact that your idea can cause in society. All of this translates the idea of value innovation for the customer (as demonstrated by Kim and Mauborgne, 2005), the more that he realizes that he needs this new product or service, the more the company will benefit in the long run. With the growth and maturation of the startup, it is also important to assess whether it is possible to add value to customers through insights and designate a new demand. Thus, the company remains strong in the market and gains more and more visibility within the platform.

On the issue of cost minimization in startups, Kim and Mauborgne (2005) explain that there are two actions that the company can use to develop new ideas on how to improve its cost composition, which are: elimination and reduction of properties. In this sense, the company needs to analyze which attributes should be reduced well below sectoral standards and which ones should be eliminated. To do so, the company must assess which of these value attributes have long served as the basis for competition in the industry, and whether there is an excess in the products or services that mimic or outperform its competition. In this way, these actions seek to significantly reduce the factors that generate the competition, thus creating a new value curve for the product, also optimizing its cost structure.

In this sense, respondents say that the company, both at the beginning and during the new business process, should be concerned about the excessive expenses that hinder the organization's leverage in the market. The actions that startups should take in these situations should also be in accordance with customer feedback analyzes, with the flexibility of modeling the market and increasing the efficiency of growing faster.

As for the effectiveness of the lean and planned strategies, in the same way as Ries (2012), the interviewee 1 explains that market trials are important, because the product development process generates collaboration and interactivity with the client, thus, their satisfaction tends to be greater, since his "preferences" and suggestions are in the product or service he consumes. The interviewee 2 , on the other hand, considers that the lean strategy can be dangerous, mainly from the financial point of view. According to Ladd (2016), these market tests are dangerous, because they detract both from the customer relationship and from the startup itself. With this, the author argues that for the company to be successful, it needs to take a strong and welldesigned business plan. Still, Ladd (2016) points out that not all negative feedback should be considered, causing startup to disrupt the product development to serve the customer, because this can give the company false market sensations, wasting and rejecting what actually would be good ideas.

Summarising, respondents point to three important factors that a digital startup needs to consider in order to define the type of planning that best suits them: time for planning, money available for investment, and the team behind the business. These factors are essential since, depending on the level of each one, the startup can be impaired during the launch of its market solution. With this, it is observed that the choice of the type of planning that a digital startup can use to obtain better market 
prospects is not only a question of the type of product or service that it will offer. This means also evaluating the other factors, already mentioned, that are important for value innovation (which is in line with Kim and Mauborgne, 2005). In this way, these factors will help the startup to have a more precise degree of the level of planning that it needs to leverage its business, always seeking to minimize and eliminate as many risks as possible during its development, maturation and growth in the market.

With regard to the steps to be followed before an idea with potential to be worked, in view of the constitution of a startup, it is noted, in the interviews, the importance attributed to the disclosure of the product or service. It is important that the person or startup discloses the product to the greatest number of people in order to quickly gain knowledge of the potential customers. Another alternative is to look for an application developer, incubator or accelerator, or even an investor who supports the idea. With this, the startup will have enough support of these to help it to develop its idea and put it in the market.

In fact, if the entrepreneur can not develop his idea and put it into practice, he needs to seek support to leverage his business. However, he needs to exercise caution in these "partnerships" and define and agree very well with the parties involved, how will be the responsibilities, the goals and the commitments with the new business. Thus, all parties will reduce or eliminate risks of actions that detract the startup by one of the parties, either by seizing the idea and then developing it without authorization, or by being held hostile to unsatisfactory results and costs.

In the question of entrepreneur focus in the case of the digital startup, respondents highlight three main points for scalable growth: mobilization of the resources that must be used to transform their ideas into reality; innovation of value for the product; and customer feedback. It is interesting to note that these points are linked to some authors already cited in the theoretical field of this paper, Ries (2012), Blank (2006) and Kim and Mauborgne (2005). For Ries (2012), there are three important steps a startup can use to evaluate their new business: build, measure, and learn. The first step is to turn ideas into products, followed by measuring customer feedback - as well as Blank (2006) - and then learning from the results. On the other hand, Kim and Mauborgne (2005) explain that the innovation of value for the product is the most essential factor for a new company in the market, because, therefore, the demand will be higher due to this "new" need.

Establishing the focus that the digital startup must prioritize at the start of its new business is one of the most important and crucial points to consider in order to achieve greater success in the short term and thus remain in the market for a long time. However, evaluating whether the company should prioritize innovation in value, communication and disclosure, cost, customer feedback or planning as a whole, for example, becomes very difficult as there is no exact formula for success. It is clear that, in addition to the factors mentioned and explained by the authors and interviewees, the type of product or service that the startup will offer to its client will significantly influence the definition of the type(s) of focus of that company. However, the startup certainly needs to be aware of what its innovation represents or can represent for its customer, so that it feels the need to "always" use that market solution.

In the case of the adopted strategies, although they can be diversified, it is observed that the errors are frequent. Even so, startups benefit from these mistakes because they bring the idea of making mistakes early and learning fast, they have as 
their essence these experiments and feedbacks within their evolution towards their innovation. What should be evaluated are the actions that the startup practices from these errors, because its main features also contains the low initial cost of the project and the differentiation or innovation of the product or service. As pointed out by Jaworski, Kohli and Sahay (2000) and Kim and Mauborgne (2005), the idea of these innovative companies to guide and lead the market for product value innovation is extremely important and transformative for today's world, where technology is one of the main pillars of resources for such innovations and/or improvements, changing the structure and behavior of the environment.

Thus, the startup needs to identify and exploit the strategy that is most appropriate according to the satisfaction of its target market. For example, to ensure the quality of the product or service, the company needs to spend a little more money, there is not a strategy that seeks to reduce and eliminate direct costs with it. In this way, these points will help the company analyze what it really needs to grow and guide the market in the face of its actions and pro-actions.

On the question of profitability of free applications, respondents agree that such applications can be profitable. As explained in the interviews, it is possible to profit from free applications, mainly, in the most used way, that is through the adds (advertisements). However, many digital companies treat this aspect in ways that users do not find healthy and interesting. A great example of these complaints happened and still happens with Youtube, where the multi-billionaire company started to place mandatory ads before the videos that the users intended to watch. This has caused a lot of claims, as the adds take away or diminish the public's interest in the platform's contents.

As pointed out by Ciccone (2017), it may be a good strategy to adopt the freemium model. With this in mind, it is important that the digital startup looks for interesting ways in which its product or service, being free, can profit from adds, for example, or in-app functionality. It is also interesting to think that the benefit that these startups bring to the market is that they are still looking for or are already creating new business models (Casadesus-Masanell; Ricart, 2010; Teixeira, 2014; Teece, 2010; Zott; Amit, 2010), innovating in the way of gaining space in a market still unknown or little explored. Therefore, from the outset, the company must seek to understand its target market and how to reach it, having a good development of its product with the innovation of value necessary for its consumers to remain faithful to its use, in addition to attracting more users.

With regard to the question about the aspects to be highlighted in the face of the trends in the field of digital startup, it is evident that the resources of technology are more used to benefit new business in digital environment (Chaffey, 2014; LAUDON; TRAVER, 2016; TURBAN, et al., 2017). However, as highlighted by the interviewees, it is necessary to guarantee reliability, security and confidentiality of data, so that the user feels more relaxed and comfortable in the use of products and services. With the knowledge of the key security risks associated with virtualization and a commitment to following best risk mitigation practices, it is possible for any organization to strike a balance between taking advantage of virtualization and maintaining the highest levels of security, making the customer experience more enjoyable, interesting and lasting. 


\section{Conclusion}

The advance in the objectives of the work became clear during the conceptual development and in the field research, because it allowed describing, analyzing and discussing the themes for a better understanding of the critical success points of a digital startup. The conceptual themes, in the scope of business models, strategies and planning of startups had the purpose of showing some of the main strands that exist in the new business, such as: the adequate level of planning; the measurement of the customer feedback; value innovation; proactive and reactive strategies to the market; and business models used in digital environment.

When thinking about the field work, the discussions and results, besides enriching the concepts addressed and studied in the bibliographic review, allowed to identify the startup processes for innovative and new companies in the market, with emphasis on the Brazilian reality, also showing which type of organizations can give support to these enterprises, the importance of social impact in these projects, the process of startup growth and the cost control. Thus, this study provides guidelines for the new entrepreneur and for new ventures.

In general, it was possible to notice that the most complex and exhausting parts of the process are: transforming the idea into a product; understand the current market; the timing for launch; and to measure customer feedback. On the other hand, the essential factor that determines the concept of the new business model is the innovation of value for the product or service in question, that is, bring to the consumer a tool or a solution that will help and improve his digital activities any time and place in an innovative and essential way.

The capital for investment should also be considered, because depending on the product or service, the startup needs to spend more or less money to start and even leverage their business. It is important to emphasize that, if the entrepreneur has the idea but does not know how to develop the technological part, such as an application, for example, he needs to find a developer or a team of developers who will assist the project and will be willing to participate assiduously during the beginning, growth and maturation of the startup.

In addition, the entrepreneur can also seek the support of accelerators or incubators, which will help the startup to grow, both in the financial part and with the technology resources available. Thus, there is also a greater cost cut, since the accelerator or the incubator provides this support for the startup. Given the relevance of the subject, it is recommended, finally, the development of new studies on the subject, that deepen, for example, the understanding of the relationship of the startups with the incubators, accelerators and investors, investigating their dynamics of operation, advantages and disadvantages, in order to subsidize new entrepreneurs in innovative businesses in digital environment, towards new business models. 


\section{References}

AMIT, R.; ZOTT, C. Creating value through business model Innovation. Sloan Management Review, v. 53, n. 3, p. 41-49, 2012.

AZEVEDO, E. M. L.; SILVA, A. C. O.; MAY, M. R. Análise do Modelo de Negócio das Ventures Builders. REGEPE - Revista de Empreendedorismo e Gestão de Pequenas Empresas, v. 7, n. 1, p. 104-129, 2018.

BARBERO, E. R.; VIEIRA, B. N. Estratégia do Oceano Azul: Relato de implantação em um setor em crise. Revista Ibero Americana de Estratégia, v. 14, n. 4, p. 135148, 2015.

BERGER, P. L.; LUCKMAN, T. A construção social da realidade. Vozes: Petrópolis, 2014.

BLANK, S. G. The Four Steps to the Epiphany: successful strategies for products that win. Winsconsin: K \& S Ranch, 2006.

BLANK, S. G. Why the Lean Startup Changes Everything. Harvard Business Review, maio 2013. Disponível em: <https://hbr.org/2013/05/why-the-lean-start-up-changeseverything >. Acesso em: 29 set. 2019.

CASADESUS-MASANELL, R.; RICART, J. E. From strategy to business models and ontotactics. Long Range Planning, v. 43 n. 2-3, p. 195-215, 2010.

CASADESUS-MASANELL, R.; ZHU, F. Business model innovation and competitive imitation: The case of sponsor-based business models. Strategic Management Journal. v. 34 n. 4, p. 464-482, 2013.

CHAFFEY, D. Gestão de e-business e e-commerce: estratégia, implementação e prática. 5 ed. Rio de Janeiro: Elsevier, 2014.

CICCONE, E. Platform ecosystem: an analysis of the business model evolution through Blockbuster and Netflix case studies. 2019. Disponível em: <https://tesi.luiss.it/20805>. Acesso em: 18 Jan 2019.

DASILVA, D. M.; TRKMAN, P. Business Model: What it is and what it is not. Long Range Planning, v. 47, n. 6, p. 179-389, 2014.

DENZIN, N. K.; LINCOLN, Y. S. O planejamento da pesquisa qualitativa: teorias e abordagens. Porto Alegre: Artmed, 2006.

FJELDSTAD, O. D.; SNOW, C. C. Business models and organisational design. Long Range Planning. v. 51, n. 1, p. 32-39, 2018.

FREDERIKSEN, D. L.; BREM, A. How do entrepreneurs think they create value? A scientific reflection of Eric Ries' Lean Startup approach. International Entrepreneurship and Management Journal, v. 13 n. 1, p. 169-189, 2017.

FOUCAULT, M. A ordem do discurso. Edições Loyola: São Paulo, 2012.

GAVA, R. Proatividade de mercado: construção de um modelo teórico. 2009. 347 f. Tese (Doutorado em Administração) - Universidade Federal do Rio Grande do Sul, Porto Alegre, 2009.

GERHARDT, T. E.; SILVEIRA, D. T. (Org). Métodos de pesquisa. Porto Alegre: Editora da UFRGS, 2009. 
GIL, A. C. Métodos e técnicas de pesquisa social. São Paulo: Atlas, 2019.

GITAHY, Y. O que é uma startup?. 2016. Disponível em: <https://exame.abril.com.br/pme/o-que-e-uma-startup/>. Acesso em: 20 Mai 2018.

GONZALEZ, I. V. D. P.; CAMPOS, F. C. Proposta de modelo conceitual de formação de estratégia de negócio a partir da integração da aprendizagem organizacional e a gestão da inovação. Gestão \& Planejamento, v. 16, n. 3, p. 473-493, 2015.

JAWORSKI, B.; KOHLI, A. K.; SAHAY, A. Market-driven versus driving markets. Journal of the Academy of Marketing Science, v. 28, n. 1, p. 45-54, 2000.

LECOCQ, X.; DEMIL, B.; VENTURA, J. Business Models as a Research Program in Strategic Management: An appraisal based on Lakatos. M@n@gement, v. 13, n. 4, p. 214-225, 2010.

KALGOVAS, B. J. The Lean Start-Up: An Exploration of the Challenges of Developing a Social Media App Business Model through Prototyping. ECIS 2015. Research-inProgress Papers, p. 1-10, 2015.

KIM, C.; MAUBORGNE, R. A Estratégia do Oceano Azul: Como criar novos mercados e tornar a concorrência irrelevante. Rio de Janeiro: Campus-Elsevier, 2005.

KIM, C.; YANG, K. H.; KIM, J. A strategy for third-party logistics systems: A case analysis using the blue ocean strategy. Omega, v. 36 n. 4, p. 522-534, 2008.

LEAVY, B. Value innovation and how to successfully incubate "blue ocean" initiatives. Strategy \& Leadership, v. 46 n. 3, p. 10-20, 2018.

LADD, T. Os limites da estratégia de estrutura enxuta para startups. Harvard Business Review Brasil, maio 2016. Disponível em: <http://hbrbr.com.br/os-limitesda-estrategia-de-estrutura-enxuta-para-startups/>. Acesso em: 30 Out 2016.

LAUDON, K. C.; TRAVER, C. G. E-commerce 2016: business, technology, society. Boston: Pearson, 2016.

MEDEIROS JÚNIOR, J. V.; AÑEZ, M. E. M; SOUSA NETO, M. V.; BEZERRA, M.H.M. Elaboração do mapa de recursos: Processo de apoio ao planejamento de um novo negócio de Internet. Revista de Administração Mackenzie. v.16, n.5, p.226-256, 2015.

MELO. I. F. Análise do discurso e análise crítica do discurso: desdobramentos e intersecções. Revista Eletrônica de Divulgação Científica em Língua Portuguesa, v. 5, n. 11, p. 1-18, 2009.

MILES, R. E.; SNOW, C. C. Organizational strategy, structure and process. New York: McGraw-Hill, 1978.

MOOGK, D. R. Minimum viable product and the importance of experimentation in technology startups. Technology Innovation Management Review, v. 2, n. 3, p. 2326, 2012.

NENONEN, S.; STORBACKA, K. Business model design: conceptualizing networkedvalue co-creation. International Journal of Quality and Service Sciences, v. 2 n. 1 , p. $43-59,2010$. 
PORTER, M. E. What is Strategy?. Harvard Business Review, v. 74, n. 6, p. 61-78, 1996.

RIES, E. A startup enxuta: como os empreendedores atuais utilizam a inovação contínua para criar empresas extremamente bem-sucedidas. São Paulo: Lua de Papel, 2012.

ROZA, R. H. Revolução informacional e os avanços tecnológicos da informática e das telecomunicações. Ciência da Informação em Revista, v. 4 n. 3, p. 03-11, 2017.

RITTER, T.; LETTI, C. The wider implications of business-model research. Long Range Planning, v. 51, n. 1, p. 1-8, 2018.

SARMENTO, M. R. C.; COSTA, L. F. L. G. O papel das aceleradoras na consolidação de novas empresas de cultura empreendedora a luz da metodologia lean startup. EmpíricaBR - Revista Brasileira de Gestão, Negócio e Tecnologia da Informação, v. 1 n. 1, p. 65-86, 2016.

SOUSA NETO, P. P.; CAVALCANTI, J. C. Análise do Modelo de Gestão da Inovação Enxuta. Revista Eletrônica de Gestão Organizacional, v. 14, p. 277-287, 2016.

SPIETH, P.; SCHNECKENBERG, D.; RICART, J. E. Business Model Innovation: The State of the Art and Future challenges for the field. R\&D Management, v. 44 n. 3, p. 237-247, 2014.

TEECE, D. J. Business Models, Business Strategy and Innovation. Long Range Planning, v. 43 n. 2-3, p. 172-194, 2010.

TEIXEIRA, L. C. M. Estratégias competitivas em modelos de negócios de bancos públicos federais. 2014. 201 f. Tese (Doutorado em Administração) - Pontifícia Universidade Católica de Minas Gerais, Belo Horizonte, 2014.

TERHO, H.; SUONSYRJÄ, S.; SYSTÄ, K.; MIKKONEN, T. Understanding the relations between iterative cycles in software engineering. In: Proceedings of the 50th Hawaii International Conference on System Sciences, p. 5900-5909, 2017.

TODESCHINI, B. V.; BOELTER, A. S.; SOUZA, J. S.; CORTIMIGLIA, M. N. Risk Management from the Perspective of Startups. European Journal of Applied Business and Management, v. 3 n. 3, p. 40-54, 2017.

TRIMI, S.; Berbegal-Mirabent, J. Business model innovation in entrepreneurship. International Entrepreneurship and Management Journal, v. 8 n. 4, p. 449-465, 2012.

TURBAN, E. et al. Electronic commerce 2018: a managerial and social networks perspective. London: Springer, 2017.

VILAÇA, M. L. C. Pesquisa e ensino: considerações e reflexões. E-scrita, v. 1 n. 2, p. 59-74, 2010.

ZOTT, C.; AMIT, R. Business model design: an activity system perspective. Long Range Planning, v. 43 n. 2, p. 216-226, 2010.

ZOTT, C.; AMIT, R.; MASSA, L. The business model: recent developments and future research. Journal of Management, n. 4, p. 1019-1042, 2011. 
43 Radrigo Hipólita Roza, Samuel Carvalho De Benedicto e André Luiz Zambalde

YANG, X.; SUN, S. L.; ZHAO, X. Search and execution: examining the entrepreneurial cognitions behind the lean startup model. Small Business Economics, p. 1-13, 2018. 